\title{
COVID-19 IN INVESTMENT ARBITRATION. A LEGAL ANSWER
}

\author{
Bianca Maria Krzizok
}

University of Zurich, Zurich, Suiza

Contacto: bianca.krzizok@gmx.ch

Recibido: 13 de abril de 2021

Aprobado: 6 de mayo de 2021

Para citar este artículo:

Krzizok, B. M. (2021). "COVID-19 in Investment Arbitration.

A Legal Answer". Prudentia Iuris, N. 92, pp. 65-96

DOI: https://doi.org/10.46553/prudentia.92.2021.pp.65-96

\begin{abstract}
During today's situation of COVID-19, States take emergency measures which will be subject to investment arbitration claims sooner or later. The aim of this paper is to provide a possible solution to such cases where the State's and the investor's interests compete with each other. By analysing cases from the $21^{\text {th }}$ century and applying my findings to hypothetical COVID-19 cases, a general answer on how to solve COVID-19 related investment disputes shall be given.
\end{abstract}

Keywords: COVID-19, Arbitration, Investment Law, Case Law, Arbitral Tribunals, Police Power, Indirect Expropriation. 


\section{COVID-19 en el arbitraje de inversiones. Una respuesta jurídica}

Resumen: En la situación actual de COVID-19, los Estados adoptan medidas de emergencia que, tarde o temprano, serán objeto de demandas de arbitraje de inversiones. El objetivo de este documento es ofrecer una posible solución a estos casos en los que los intereses del Estado y del inversor compiten entre sí. Mediante el análisis de casos del siglo XXI y la aplicación de mis conclusiones a casos hipotéticos de COVID-19, se dará una respuesta general sobre cómo resolver las disputas de inversión relacionadas con COVID-19.

Palabras clave: COVID-19, Arbitraje, Derecho de inversiones, Jurisprudencia, Tribunales Arbitrales, Poder de Policía, Expropiación indirecta.

\section{COVID-19 nell'arbitrato sugli investimenti. Una risposta legale}

Sommario: Nell'attuale situazione creatasi a causa del virus COVID-19 gli Stati adottano misure di emergenza che prima o poi saranno soggette a richieste di arbitrato per quanto concerne soprattutto gli investimenti. Lo scopo di questo articolo è di fornire una possibile soluzione quando gli interessi dello Stato e quelli dell'investitore sono in competizione tra di loro. Analizzando alcuni recenti casi e applicando i miei risultati a casi ipotetici di COVID-19, si cercherà di dare una risposta generale su come si possano risolvere le controversie di investimento legate al COVID-19.

Parole chiave: COVID-19, Arbitrato, Diritto degli investimenti, Giurisprudenza, Tribunali Arbitrali, Potere di polizia, Espropriazione indiretta. 


\section{Introduction*}

COVID-19 leaves us with extraordinary circumstances, which States address with emergency measures to manage both the current health and the economic crisis ${ }^{1}$. Also, when the pandemic will be over, there will be a long recovery phase during which economic measures will have to be taken to restart the economies of States devastated by the pandemic. History tells us that emergency measures often generate arbitration claims ${ }^{2}$. The United Nations Conference on Trade and Development also anticipates that there will be a large number of investment arbitrations brought against States in respect of these COVID-19-related measures ${ }^{3}$. That is the case since an investor might see the State's current emergency measures as an indirect, compensable expropriation of his investment ${ }^{4}$. The State would then argue that its measures are inherent to its right to regulate in the public interest, the so called Police Power, and thus constitute ordinary regulatory, non-compensable, measures ${ }^{5}$. The two competing interests, the State's interest to use its Police Power and the investor's interest for investment protection, will then come into direct conflict. To find a balance between these two interests is of particular relevance for the following reasons. If the Tribunal gives more weight to the State's interest, its decision might constitute a carte blanche for the government, opening the doors for

* The author thanks Prof. Dr. iur Elisabetta Fiocchi Malaspina and Prof. Dr. iur. Santiago Legarre for their guidance and support.

1 As the WHO has declared the current situation a public crisis of international concern due to the Public Health threat of the virus, the IMF has warned, the economic downturn in 2020 will be the most severe since the Great Depression; See WHO (2020). Statement on the second meeting of the International Health Regulations. Emergency Committee regarding the outbreak of novel coronavirus (2019-nCoV). IMF. (2020). The Great Lockdown. World Economic Outlook Reports.

2 E.g. several foreign investors brought claims against Argentina in the late 1990s and early 2000s to challenge the economic emergency measures that Argentina adopted as a response to the severe economic crisis it faced. Likewise, several ISDS claims were brought against Egypt when it took steps to counter the anti-government protests and armed rebellions that struck much of the Arab world in early 2010s (also known as the Arab-spring); See Ranjan (2020) 209.

3 UNCTAD (2020). Investment Policy Responses to the COVID-19 Pandemic. Investment Policy Monitor Special Issue (4).

4 An indirect expropriation does not involve a physical taking, differently from a direct expropriation, but still has an effect on the individual's property.

5 UNCTAD (2012). Expropriation, A Sequel. UNCTAD/DIAE/IA/2011/7, 79. Black's Law Dictionary. The legal principles used to sustain the police power of the state are the civil law concepts sic utere tuo at alterum non leadas (use what is yours in a way that does not injure others) and salus publica suprema lex esto (public safety is the supreme law). See Galva/ Atchison/Levey (2005) 20-27. See Legarre (2007) for the historical origin of this term. 
abusive behaviour. On the other hand, if the Tribunal gives more weight to the investor's interest, it will substantially limit the State's regulatory space. Eventually, the mere possibility of a dispute with a powerful investor can exert a chilling effect on a State's decisions to regulate in the public interest ${ }^{6}$. Also, an emphasis on the investor's interests would mostly affect the developing states. At a time when they have to rebuild their economies, they will hardly sustain the impact of claims. Claims could then deepen the inevitable economic crisis.

To avoid such scenarios, this paper wishes to show a possible solution to balance the State's and the investor's interests in COVID-19 related indirect expropriation claims. Two hypothetical COVID-19 cases shall be solved as a way of illustration. Even though there is no formal stare decis in international investment law, there is still a de facto stare decisis, which tends to promote uniformity in arbitral proceedings ${ }^{7}$. Accordingly, Arbitral Tribunals must treat similar cases in a similar way. For this reason, I chose the most similar cases of the $21^{\text {th }}$ century to a possible COVID-19 case. This way, I argue, these cases can serve as a guiding to solve a possible COVID-19 case. The paper conforms to the following structure. First, I shall introduce the legal doctrine on the topic of indirect expropriation in part I which will be applied to practice in part II. Part II.1 will start with a case analysis reading public health regulations and part II.2 will deal with cases regarding economic regulations ${ }^{8}$. Each part represents the consensus

6 The Regulatory Chill is a hypothesis stating that in some circumstances, governments will respond to a high (perceived) threat of investment arbitration by failing to enact or enforce bona fide regulatory measures (or by modifying measures to such an extent that their original intent is undermined, or their effectiveness is severely diminished). See e.g. Tienhaara (2011). International Institute for Sustainable Development, Working Paper (1999) 5. E.g. Commentators have reported that in 2002 a group of mainly foreign-owned mining companies threatened to commence international arbitration against the Government of Indonesia in response to its ban on open-pit mining in protected forests. Six months later, the Ministry of Forestry agreed to change the forest designation from protected to production forest. See Gross (2002) 894. Feldman v. Mexico (2002) 103: "Governments must be free to act in the broader public interest through protection of the environment. Reasonable governmental regulation of this type cannot be achieved if any business that is adversely affected may seek compensation, and it is safe to say that customary international law recognizes this".

7 E.g. Kaufmann-Kohler (2007) 374. Caratube International Oil Company LLP $v$. Kazakhstan, Saipem S.p.A. v. Bangladesh (2007) 67: “[...] a series of consistent cases should be followed, unless the Tribunal has compelling contrary grounds not to".

8 The differentiation between financial regulations and economic regulations is beyond the scope of this paper: See e.g. Blankenburg (2009) 531-538. I summarize both kinds of regulations under the term economic regulations, as suggested by the IMF and OECD: IMF (1999). The 1994 Mexican Economic Crisis. OECD (2017). The Role of Economic Regulators in the Governance of Infrastructure. 
regarding said policy objectives in international investment law jurisprudence. Their division considers that a State will apply public health as well as economic regulations to address the COVID-19 crisis. Part III shall apply these findings to two hypothetical COVID-19 cases and part IV shall conclude this paper.

\section{The Battle of Finding the Right Balance in Legal Doctrine}

In observing the growing tide of arbitral jurisprudence, three streams have emerged in order to establish the balance between the State's and the investor's interests: the Sole Effects doctrine, the Police Powers doctrine and the mitigated Police Powers doctrine. All doctrines constitute a possible way to assess whether a measure constitutes an indirect expropriation or an ordinary regulatory measure. Whilst the Sole Effect doctrine solely concentrates on the effects of the State's measure on the foreign property, the Police Powers doctrine only focuses on the alleged goal, the purpose behind the State's measure. While some accept a strict, radical application of the Police Power doctrine (every measure that falls within the identified policy areas is immune from a finding of indirect expropriation $)^{9}$, a new tendency is developing towards a mitigated Police Powers doctrine ${ }^{10}$. According to this mitigated Police Powers doctrine, other elements, such as proportionality or non-discrimination are combined with the traditional strict approach ${ }^{11}$. Since the measure's effect might be taken into account as well, this doctrine represents a compromise between the Sole Effects and Police Powers doctrine. After 2000, a consistent trend in favour of the exercise of the mitigated Police Powers doctrine

9 See Christie (1962) 331-332, 338. Herz (1941) 253. Friedman (1953) 141-42. S.D. Myers, Inc. v. Government of Canada (2000) 281.

10 The term "mitigated" Police Powers doctrine is borrowed from Bücheler (2015) 129132. See Garcia-Amador (1959), Special rapporteur, Fourth Report on State Responsibility, Extract from the Yearbook of the International Law Commission, Vol. II, 44. Harvard Draft Convention on International Responsibility of States (1961) Art. 10(5). American Law Institute, Restatement (Third) Foreign Relations of the United States (1987), Vol. 1, 712, comment (g). OECD, Working Paper on International Investment, Indirect Expropriation and the Right to Regulate in International Investment Law (2004) 5.

11 E.g. Renee Rose Levy de Levi v. The Republic of Peru (2014) 46. Quiborax S.A., Non Metallic Minerals S.A. and Allan Fosk Kaplún v. Plurinational State of Bolivia (2015) 202. Glamis Gold, Ltd. v. the U.S. (2009) 356. 
emerged $^{12}$, which can be confirmed in my following case analysis ${ }^{13}$. Which exact factors will be assessed under this approach, depends on the circumstances of each individual case. In the next part, I shall provide an overview of these factors.

\title{
II. Case Analysis of the $21^{\text {th }}$ Century
}

\section{II.1. Limits of Public Health Regulations in Case Law of the $21^{\text {th }}$ Century}

\author{
II.1.1. Tecnicas Medioambientales Tecmed S.A. v. United \\ Mexican States (2003)
}

In the case Tecnicas Medioambientales Tecmed S.A. v. United Mexican States (Tecmed $v$. Mexico), the applicable arbitration rules were based on ICSID Additional Facility, and the applicable investment treaty between the State and the investor was the Mexico-Spain BIT. The Spanish investor, Tecmed Medioambientales Tecmed S.A., alleged that Mexico had indirectly expropriated its investment in a landfill for hazardous industrial waste in Las Víboras. Mexico had denied the operating permit of the said landfill. The investor found that this denial constituted an indirect expropriation. In determining whether the measure constituted an indirect expropriation of the investment, the Tribunal, first, analysed the measure's effect on

12 Bonnitcha (2014) 230. Fortier/Drymer (2008) 326. Newcombe (2005) 54. UNCTAD (2012). Expropriation: A Sequel, 94. UNCTAD (2019). Trade and Development Board, Investment, Enterprise and Development Commission, $11^{\text {th }}$ session, Recent developments in the international investment regime: Taking stock of phase 2 reform actions, 9 (reporting from a sample of 862 BITs signed between 1962-2011). E.g. El Paso Energy International Company v. The Argentine Republic (2011) 237ff. EDF (Services) Limited v. Romania (2009) 293. U.S. Model BITs (2004, 2012). Canada Model BITs (2004, 2012). The EU-Canada Comprehensive Economic and Trade Agreement (2016). EU-Singapore-FTA (2018).

13 Since no investment treaties were in place that could draw a distinguishable line between a regulatory measure and an indirect expropriation, Tribunals based their assessment on customary international law and previous jurisprudence. Tecmed v. Mexico (2003) 116, 121. Chemtura v. Canada (2010) 121. Methanex Corporation v. United States of America (2005) 15; Philipp Morris v. Uruguay (2016) 290, 310, 317; LG\&E v. Argentina, Decision on Liability (2006)185. Marfin v. Republic of Cyprus (2018) 827. Saluka v. The Czech Republic (2006) 254, 296. Fireman's Fund v. Mexico (2006) 136: The Tribunals relied upon Art. 31(3)(c) of the VCLT which requires that treaty provisions are interpreted in the light of any relevant rules of international law applicable to the relations between the parties, a reference which includes customary international law. The mitigated Police Powers doctrine was seen as a part of customary international law and thus applied. 
the investor, second, whether the measure had a bona fide public purpose and third, whether the investor had legitimate expectations that the State would refrain from the contested measure. New in the Tribunal's analysis was the fourth step, the test of proportionality, which was based on ECtHR jurisprudence ${ }^{14}$. This test required there to be a reasonable relationship between the measure's purpose and the measure's effect on the investor and the investor's legitimate expectations. Beginning its analysis with the measure's effect, the Tribunal argued that a measure only needed to be compensated if it led to a radical deprivation of the economical use and enjoyment of the investment and related rights ${ }^{15}$. The Tribunal additionally opined that the measure must be irreversible, permanent and not temporary to constitute an indirect expropriation. In this case, the closing of the investment left the investor with no option to economically use and enjoy the investment. Also, the measure was permanent and irrevocable since the denial of the permit was non-renewable ${ }^{16}$. The Tribunal thus held that the investor was substantially deprived ${ }^{17}$. In the Tribunal's second step of its analysis, the examination of Mexico's purpose behind the measure, the Tribunal assessed whether the measure's purpose was bona fide to remedy harmful health and environmental impacts as alleged by Mexico. The fact that the investor's operation of the investment never compromised the ecological balance, the protection of the environment or the health of the people, left the Tribunal with no doubt that the actual reason behind the measure had not been environmental and health directed. It noted that the actual reason behind the measure was to deal with socio-political difficulties created by community pressure against the investment ${ }^{18}$. Thus, the Tribunal denied the measure's bona fide public purpose. Regarding the investor's legitimate expectations, the Tribunal found that when entering into an agreement, the State and the investor created the means for the investor to be able to operate a hazardous waste landfill in Las Víboras for at least ten years ${ }^{19}$. The location in Las Víboras had served for this purpose for five years and there was no reason for the investor to doubt that

14 Mellacher and Others v. Austria (1989) 24. Pressos Compañía Naviera and Others v. Belgium (1995) 19. Matos e Silva, Lda., and Others v. Portugal (1996) 19.

15 Thus, the degree of deprivation was analysed: Tecmed $v$. Mexico (2003) 115, 119, 141.

16 Additionally, the investor could not exploit any form of the investment permanently because the landfill could not be used for a different purpose since hazardous waste had accumulated there for ten years which ruled out any possible sale in the real estate market; $c f$. more details: Ibid. 117.

17 Ibid.

18 Ibid. 89, 148.

19 Ibid. 88. 
this would not be the case anytime soon ${ }^{20}$. Thus, by considering the investment's past and the State's promises, the investor had legitimate expectations that the government would refrain from any deprivation of its investment. In the Tribunal's last step, its proportionality test, first, the Tribunal weighted the measure's real (mala fide) purpose, i.e. the community pressure, against the measure's effect. It concluded that the community pressure alone could not counterbalance the measure's effect, since only small groups of people demonstrated at the landfill and the political pressure was thus not massive, nor an emergency, and of a small degree. On the other hand, the effect on the investor was radical. Thus, the radical effect outweighed the measure's mala fide purpose, bearing the low necessity of the measure in mind. Then, balancing the measure's mala fide purpose, considering its low necessity, against the investor's legitimate expectations, the measure's mala fide purpose was outweighed by the legitimate expectations again ${ }^{21}$. Based on the above, the State's measure was to be regarded as an indirect compensable expropriation.

\section{II.1.2. Methanex Corporation v. United States of America} (2005)

In the case Methanex Corporation $v$. United States of America (Methanex $v$. U.S.), the applicable arbitration rules were based on UNCITRAL (1976) and the applicable investment treaty between the State and the investor was the NAFTA. The Canadian investor, Methanex Corporation, manufactured methanol, which was used as an ingredient in a gasoline additive commonly called Methyl-tert-butylether (MTBE) in California. The State of California banned the use of MTBE as a gasoline additive. The investor alleged that this ban on MTBE amounted to an indirect expropriation of its investment. The Tribunal noted that to decide whether a measure constituted a regulatory measure or an indirect expropriation, the following factors must be assessed. First, the Tribunal looked at the measure's nondiscriminatory nature, second, at the measure's bona fide public purpose, third, whether the measure was enacted in accordance with the investor's due process rights and, fourth, whether the investor had any legitimate expectation. First, regarding the non-discriminatory nature of the measure, the Tribunal analysed the measure in the light of any sectional or racial

20 Ibid. 117, 149, 150: The permit was based on a declaration, which projected a useful life of ten years for the landfill.

21 Ibid. 151. 
prejudice and denied the existence of such a prejudice and hence a discrimination $^{22}$. Second, regarding the measure's bona fide public purpose, the Tribunal relied on an independent scientific verification ${ }^{23}$. This verification proved that MTBE was contaminating groundwater in the State and thus needed to be abolished for health reasons ${ }^{24}$. For this reason, the Tribunal affirmed the measure's bona fide public purpose. Third, regarding the investor's due process rights, the Tribunal affirmed a lack of due process in the case of a manifest failure of justice in judicial proceedings or in the case of a complete lack of transparency ${ }^{25}$. In the case at hand, the scientific verification process was carried out according to law in an open and informed debate. Thus, there was no failure of justice or lack of transparency and the investor's due process rights were observed ${ }^{26}$. Fourth, regarding the investor's legitimate expectations, the Tribunal assessed whether the State had given any specific commitments, promising to refrain from a harmful regulation. The Tribunal denied any specific commitments given by the government and noted that the investor should have been aware of the political economy of the market it entered. The Tribunal specified that the area of investment in question had a particular public interest in the protection of health and the environment. It was subject to constant public and legislative control, which had in the past already prohibited or restricted the use of chemical compounds like MTBE for health reasons ${ }^{27}$. Thus, the investor's legitimate expectations were denied. For all the above reasons, the Tribunal decided that the investor's claim of an alleged indirect compensable expropriation failed.

\section{II.1.3. Chemtura Corporation v. Government of Canada (2010)}

In the case Chemtura Corporation v. Government of Canada (Chemtura $v$. Canada), the applicable arbitration rules were based on UNCITRAL (1976) and the applicable investment treaty between the State and the investor was the NAFTA. The U.S. investor, Chemtura Corporation, claimed that Canada had indirectly expropriated its investment, lindane-based

22 Methanex v. U.S (2005) Part IV Chapter C 26, quoting: Loewen Group, Inc. and Raymond L. Loewen v. United States of America (2003) 124-8.

23 Ibid. Part IV Chapter E 20: "California ordered a careful assessment of the problem".

24 Ibid. Part III Chapter A 101.

25 Ibid. Part IV Chapter C 7, quoting Waste Management, Inc. v. United Mexican States (2004) 98-99.

26 Ibid. 8.

27 Ibid. Part IV Chapter D 9. 
products, by banning lindane, a toxic chemical pesticide. The Tribunal first investigated the measure's effect, second, whether the measure was made for a bona fide public purpose, third, whether the measure observed the investor's due process rights, fourth, whether the measure was non-discriminatory and fifth, whether the investor had legitimate expectations ${ }^{28}$. Beginning its analysis with the measure's effect on the investment, the Tribunal applied the substantial deprivation test ${ }^{29}$. The Tribunal denied a substantial deprivation for the following three reasons. First, sales of lindane products were only a small part of the investor's overall sales ${ }^{30}$, second, the corporation remained operational, and its sales continued an ascending trend ${ }^{31}$ and third, the investor remained in control of its investment at all relevant times ${ }^{32}$. Regarding the measure's bona fide public purpose, the Tribunal based its assessment on the measure's scientific verification. However, it noted that it was not its task to determine whether certain use of lindane was dangerous. The rule was not to second-guess the correctness of the science-based decision-making of highly specialized national regulatory agencies ${ }^{33}$. The assessment of the public purpose must be conducted in concreto, according to specific circumstances in each case ${ }^{34}$. In casu, the Tribunal added that irrespective of the state of the science, it could not ignore the fact that lindane had raised increasingly serious concerns nationally and internationally and that lindane was in the list of chemicals designated for elimination under the Stockholm Convention on Persistent Organic Pollutant. Lindane was thus known as a health and environment hazard ${ }^{35}$. This international consensus, including Canada's international obligations, served as evidence for the measure's bona fide public purpose ${ }^{36}$. Then, the Tribunal analysed whether the investor's due process rights were observed. The Tribunal defined a breach of due process as a non-transparent and nonopen process behind the measure. In casu, the record showed that the investor was made aware of the importance of exposure risk and was asked to provide information on this matter but failed to take advantage of these opportunities ${ }^{37}$. Thus, the debate surrounding the measure was open and

28 Chemtura v. Canada (2010) 257.

29 This deprivation was called radical in Tecmed v. Mexico (2003) 115. Chemtura v. Canada (2010) 245, 249 .

30 Approximately 10 percent, Ibid. 260.

31 Ibid. 264.

32 Ibid.

33 Ibid. 134

34 Ibid. 123.

35 Ibid. 29.

36 Ibid. 135-6, 138.

37 Ibid. 149, 152. 
transparent and there was no breach of the investor's due process rights. After this assessment, the Tribunal discussed whether the investor was treated in a non-discriminatory way, meaning, on an equal footing with other similarly situated investors. There was evidence that the State applied the same control and measure equally on all similarly situated investors and thus in a non-discriminatory way ${ }^{38}$. As a last step, the Tribunal examined the investor's legitimate expectations. The Tribunal found that the industry's regulatory pattern must be considered. It noted that as a sophisticated registrant experienced in a highly-regulated industry, the investor could not reasonably ignore the State's practices and the associated risks ${ }^{39}$. For this reason, the Tribunal denied the investor's legitimate expectations. In sum, the measure did not constitute an indirect compensable expropriation ${ }^{40}$.

\section{II.1.4. Philip Morris Brands Sàrl and ors v. Oriental Republic of Uruguay (2016)}

In the case Philip Morris Brands Sàrl and ors v. Oriental Republic of Uruguay (Philipp Morris v. Uruguay), the applicable arbitration rules were based on ICSID and the applicable investment treaty between the State and the investor was the Switzerland-Uruguay BIT. The Swiss investor, Philipp Morris Brands Sàrl and ors, had invested in a company for the production and distribution of tobacco in Uruguay. The investor argued that by imposing control measures on tobacco, Uruguay had indirectly expropriated its investment. Uruguay's measures were divided into two. The first measure, the government's adoption of a Single Presentation Requirement (the SPR) precluded tobacco manufacturers from marketing more than one variant of cigarette per brand family. The second measure, the 80/80 Regulation, regulated the size of graphic health warnings appearing on cigarette packages. In order to establish whether the investor had been indirectly expropriated, the Tribunal first looked at the measures' effect. Second, the Tribunal examined the measures' bona fide public purpose, third, the measures' discriminatory nature and fourth, whether the measures were proportionate $^{41}$. First, regarding the measures' effect, the Tribunal applied the

38 Ibid. 236.

39 Ibid. 145.

40 Ibid. 266.

41 These factors were inter alia based on the Harvard Draft Convention. The Third Restatement of the Foreign Relations Law of the United States of 1987. OECD Draft Convention on the Protection of Foreign Property (1967). U.S. Model BITs, (2004,2012). Canada Model BITs (2004, 2012). EU-Canada Comprehensive Economic and Trade Agreement (2016). EUSingapore-FTA (2018). 
substantial deprivation test. The Tribunal reasoned that the determinative factors were the intensity and duration of the economic deprivation suffered by the investor as a result of such measures ${ }^{42}$. It was not seen as enough that while the investment had grown more profitable since 2011, it would have had been even more profitable without the challenged measures ${ }^{43}$. In the Tribunal's view, as long as sufficient value remained after the measures were implemented, there would be no expropriation. Second, the Tribunal examined the measures' bona fide public purpose ${ }^{44}$. Regarding this factor, the Tribunal based its assessment on the State's national and international legal obligations, and on WHO guidelines on tobacco consumption ${ }^{45}$. It concluded that these norms were the legal basis for the exercise of the State's right to regulate since they proofed that tobacco consumption had long been a tightly regulated area in other States as well and that its harmful nature was based on scientific consensus ${ }^{46}$. The Tribunal then discussed the margin of appreciation of the Government of Uruguay by referring to the jurisprudence of the ECtHR ${ }^{47}$. Accordingly, the sole inquiry for the Tribunal was whether or not there was a manifest lack of reasons for the legisla$\operatorname{tion}^{48}$. In the Tribunal's view, the present case concerned a legislative policy decision taken against the background of a strong scientific consensus as to the lethal effects of tobacco. Some limit had to be set and the balance to be struck between conflicting considerations was very largely a matter for the government ${ }^{49}$. Thus, due to the international and scientific consensus on the measures' purpose, the Tribunal affirmed the measure's bona fide public purpose and gave enough policy space to the State. Third, regarding the measures' non-discriminatory nature, the Tribunal found that the measures were non-discriminatory since they applied to foreign and domestic investors alike ${ }^{50}$. Fourth, regarding the measure's proportionality, like the Tribunal in Tecmed $v$. Mexico, the Tribunal balanced the measures' purpose against its effect ${ }^{51}$. But the Tribunal here differently stated that the proportionality test involved an analysis of the bona fide nature of a measures' purpose. Thus, a measure could only be proportionate to its effects if it was

42 Philipp Morris v. Uruguay (2016) 287, 295.

43 Ibid. 284, 286, quoting LG\&E v. Argentina, Decision on Liability (2006) 191.

44 Ibid. 287, 290.

45 Ibid. 302-304. See for more details ibid. 95, 404.

46 Ibid. 306, 388, 418.

47 James and others v. United Kingdom (1986) 46. Broniowski v. Poland (2005) 149.

48 Philipp Morris v. Uruguay (2016) 399, 805, quoting Electrabel S.A. v. Republic of Hungary (2012) 8.35.

49 Ibid. 418.

50 Ibid. 402.

51 Ibid. 139. 
done with a bona fide purpose. In contrast, the Tribunal in Tecmed $v$. Mexico undertook its proportionality test even considering a mala fide purpose. The Tribunal in Philipp Morris v. Uruguay found that the measures, in light of their necessity, were proportionate compared to the limited adverse impact on the investor's business ${ }^{52}$. Considering the foregoing, the Tribunal concluded that the measures were ordinary regulatory measures. As such, they could not constitute an indirect compensable expropriation of the investor's investment ${ }^{53}$.

\section{II.2. Limits of Economic Regulations in Case Law of the $21^{\text {th }}$ Century}

\section{II.2.1. LG\&E Energy Corp., LG\&E Capital Corp. and LG\&E International, Inc. v. Argentine Republic (2002)}

In the case $L G \& E$ Energy Corp., LG\&E Capital Corp. and LG\&E International, Inc. v. Argentine Republic ( $L G \& E v$. Argentina), the applicable arbitration rules were based on ICSID and the applicable investment treaty between the State and the investors was the Argentina-US-BIT. The U.S. investors, LG\&E Energy Corp., LG\&E Capital Corp. and LG\&E International Inc., alleged that Argentina had indirectly expropriated their investment, a shareholding interest in three local gas distribution companies. These companies were granted licenses for 40 years in the early 1990s. When granting the licenses, in order to attract foreign investors, Argentina enacted legislation which guaranteed that that automatic semi-annual adjustments of tariffs for gas distribution would be based on the U.S. Producer Price Index (PPI $)^{54}$. However, Argentina suspended the U.S. PPI and thus froze the tariffs instead to adjust them. The investors claimed that this suspension indirectly expropriated their investment. To decide whether Argentina's measure constituted a regulatory measure or an indirect expropriation, the Tribunal first assessed the measure's effect, second, its bona fide public purpose, third, the investors' legitimate expectations and fourth, the measure's proportionality ${ }^{55}$. The Tribunal, first, regarding the effect, held that there must be a severe and permanent deprivation of the rights in the investment

52 Ibid. 405, 410, 417, 420, 590.

53 Ibid. 419.

$54 L G \& E v$. Argentina, Decision on Liability (2006) 56.

55 These factors were based on the American Law Institute's Restatement (Third) of the Foreign Relations Law of the United States and Too v. Greater Modesto Insurance Associates (1989). 
or almost complete deprivation of the value of the investment for there to be an expropriation ${ }^{56}$. This deprivation was defined as a situation where a party no longer was in control of the investment or where it could not direct the day-to-day operations of the investment ${ }^{57}$. The Tribunal found that, although the measure especially impacted the earnings that the investor expected, it did not deprive the investors of the right to enjoy their investment. The investors had not lost control over their shares in the licensees, nor were they unable to direct the day-to-day operations of the licensees in a manner different than before the measures were implemented. Thus, the effect of Argentina's measure was not permanent on the value of the investors' shares, and the investment had not ceased to exist ${ }^{58}$. Second, regarding the measure's bona fide public purpose, the Tribunal found evidence that a period of crisis existed by analysing parameters as economic indicators, the existence of a state of necessity and in concreto manifestations such as the high increase of poverty rates and the nationwide health emergency ${ }^{59}$. The Tribunal found that due to these facts, the conditions in Argentina called for immediate, decisive action to restore civil order and to stop the economic decline ${ }^{60}$. At the time, the U.S. were experiencing a high inflationary period, while Argentina was experiencing a significant deflationary period. Argentina considered that the pending tariff adjustments based on the U.S. rate were unreasonable because they would result in a significant increase in utility rates within a recessionary and deflationary context. Increasing utility rates would lay an excessive burden on the citizen and the overall economy ${ }^{61}$. In this sense, the Tribunal recognized that Argentina's suspension of the PPI adjustment of tariffs was a necessary and legitimate way of protecting its social and economic system ${ }^{62}$. Thus, the measure's bona fide public purpose was affirmed. Third, regarding the legitimate expectations, the Tribunal reasoned that the investors' expectations must be based on the conditions offered by the host State at the time of the investment ${ }^{63}$. However, the investors' fair expectations could not fail to consider parameters such as business risk or industry's regular patterns ${ }^{64}$. In this case, Argentina prepared a regulatory framework that addressed the specific concerns

56 Ibid. 198-200.

57 Ibid. 52, quoting Pope \& Talbot v. The Government of Canada (2000) 185-200, 51.

CME Czech Republic v. Czech Republic (2001) 604, 57, 192. Tecmed v. Mexico (2003) 115.

58 Ibid. 200.

59 Ibid. 68, 228, 229. See for more examples ibid. 233, 234, 235.

60 Ibid. 240.

61 Ibid. 242.

62 Ibid.

63 Ibid. 190.

64 Ibid. 197, quoting the Oscar Chinn affair (1934). 
of foreign investors with respect to the country risks involved in Argentina. Considering these risks, the investors relied upon certain key guarantees, such as the semi-annual PPI adjustments. Having created specific expectations among investors, Argentina was thus bound by its obligations concerning the investment guarantees. The Tribunal found that Argentina went too far by completely dismantling the very legal framework constructed to attract investors. It thus concluded that the investors' legitimate expectations could be affirmed ${ }^{65}$. Fourth, regarding the measure's proportionality, the Tribunal determined that it must first balance two competing interests: the measure's effect with the measure's bona fide public purpose ${ }^{66}$. As a next step, the Tribunal balanced the measure's bona fide public purpose with the investor's legitimate expectations ${ }^{67}$. Referring to its notes on the measure's effect, the Tribunal found that in the balancing exercise at hand, where there was no deprivation of the investors' investment and where the measure's bona fide public purpose was strongly significant in its terms of necessity, this last factor outweighed the measure's effect ${ }^{68}$. Interestingly, the Tribunal did not find that the investors' legitimate expectations were enough to turn the measure into an expropriation. It found that since Argentina's economic crisis was a state of necessity, the measure's bona fide public purpose trumped the investors' legitimate expectations. However, the non-met legitimate expectations constituted a breach of the fair and equitable treatment standard, which in this case still led to a compensation payment ${ }^{69}$. In sum, the Tribunal held that the investment had not been indirectly expropriated and thus no compensation was to be paid due to this reason ${ }^{70}$.

\section{II.2.2. Fireman's Fund Insurance Company v. Mexico (2006)}

In the case Fireman's Fund Insurance Company v. Mexico (Fireman's Fund v. Mexico), the applicable arbitration rules were based on ICSID and the applicable investment treaty between the State and the investor was the NAFTA. The U.S. investor, Fireman's Fund Insurance Company, alleged that Mexico indirectly expropriated its investment. The investor had invested in dollar-nominated debentures issued by the Mexican bank BanC-

65 Ibid. 136.

66 Ibid. 189.

67 Ibid. 195.

68 Ibid. 60.

69 See LG\&E v. Argentine Republic, Award (2007).

70 LG\&E v. Argentine Republic, Decision on Liability (2006) 198-200. 
recer. The peso-nominated debentures were bought by Mexican nationals. In the aftermath of the Mexican economic crisis, in the year 1997, the financial position of many banks, including BanCrecer, deteriorated again. For that reason, to protect Mexican nationals from losses regarding their peso-nominated debentures, they were immediately paid back the full cash value of their debentures. The investor claimed that Mexico had improperly denied its request for similar treatment of its dollar-nominated debentures, which continued to significantly decrease in value. The investor found that this denial had indirectly expropriated its investment. The Tribunal first assessed the measure's effect, second, its bona fide public purpose, third, its discriminatory nature and fourth, whether the investor had legitimate expectations. First, regarding the measure's effect, the Tribunal held that the taking must be a substantially and complete deprivation of the economic use and enjoyment of the rights to the property or of identifiable distinct parts thereof. Also, the taking must be permanent. The Tribunal noted that the investor's debentures had already suffered a significant loss of value prior to Mexico's repurchase of the Peso debentures. Further, the Tribunal did not see how Mexico's denial of the repurchase would have deprived the investor of its ability to sell its investment to a different interested buyer. Thus, the investor was not deprived of its economic use and the Tribunal denied a substantial and complete deprivation. Second, regarding the measure's bona fide public purpose, the Tribunal noted that there was little to no value left of the investment prior to the State's measure. Even a discriminatory lack of effort by a host State to rescue an investment that had become virtually worthless was not mala fide. The Tribunal noted that the financial position of many banks, including BanCrecer, had deteriorated and thus measures needed to be taken. These facts gave the Tribunal enough evidence for a bona fide public purpose. Regarding the investor's legitimate expectations, the Tribunal found that promises made by the State could have set such expectations. In this case, there were no promises that the State would repurchase US-nominated debentures. Further, the Tribunal noted that the investor was aware that its investment was risky both in terms of the economic conditions in Mexico at the time and in terms of the specific financial institution that issued the dollar debentures, since Mexico was in the process of recovering from a major economic crisis ${ }^{71}$. Thus, by taking the investment's past financial situation and eventual promises into account, the Tribunal found that there were no reasonable investor-backed expectations created by Mexico. Regarding the non-discriminatory nature of the measure, the Tribunal found that similar situated investors should

71 Fireman's Fund v. Mexico (2006) 48, 180. 
be treated equally if there was no reasonable justification for a differentiation. It found that if one group of debentures was to be saved, all debentures should be saved and thus repurchased by the State ${ }^{72}$. Since Mexico did not give any reason for its different treatment regarding peso-nominated debentures, the Tribunal found this differentiation to be discriminatory ${ }^{73}$. However, the Tribunal concluded that this discrimination did not mean that the State's measure constituted an indirect expropriation. Discriminatory treatment was used as only one of the factors to distinguish between a compensable expropriation and a non-compensable regulation by a host State $^{74}$. All assessed factors needed to be weighed against each other. While this balancing exercise was not defined as a proportionality test, the Tribunal assessed the measure's proportionality this way. It found, however, that since there was no substantial effect of the measure and a bona fide public purpose, the discriminatory treatment would be outweighed. Nevertheless, the discriminatory treatment violated the national treatment and minimum standard of treatment treaty provisions ${ }^{75}$. But even in regard to these violations, no compensation was due since the investor's only claim was that the State had indirectly expropriated its investment. Based on the above, this claim failed, and the Tribunal found that the State's denial of repurchase did not constitute an indirect compensable expropriation.

\section{II.2.3. Saluka Investments B.V. v. The Czech Republic (2006)}

In the case Saluka Investments B.V. v. The Czech Republic (Saluka v. The Czech Republic), the applicable arbitration rules were based on UNCITRAL (1976) and the applicable investment treaty between the State and the investor was the Netherlands-Czech Republic BIT. The Dutch investor, Saluka Investments B.V., alleged that its investment, shares in Ipbinvestiční Poštovní Banka (IPB), a Czech Bank, was indirectly expropriated by the Czech Republic. Due to the Czech Republic economic crisis, the IPB was brought under forced administration by the Czech National Bank, authorized by the State. First, the Tribunal assessed the measure's effect, second, its bona fide public purpose and third, its proportionality ${ }^{76}$. First,

72 Ibid. 203: "If there is a "haircut" for holders of debentures, all should be shaven. Conversely, if one is allowed to escape the hands of the barber, the other should be allowed to escape as well".

73 Ibid. 187.

74 Ibid. 206.

75 Ibid. 203.

76 These factors were based on the Harvard Draft Convention on the International 
regarding the effect, the Tribunal noted that for the effect to constitute an indirect expropriation, the measure must have impaired the operation, management, maintenance, use, enjoyment or disposal of the investment and thus substantially have deprived the investor ${ }^{77}$. The Tribunal found that a forced administration of IPB met these conditions since the investor lost its managerial control over the bank and the IPB shares it held were rendered worthless ${ }^{78}$. In sum, the investor was substantially deprived of its investment. Regarding the measure's bona fide nature, the Tribunal found that the State's measure was indeed motivated bona fide. First, by referring to the State's national law, the Tribunal found that the State enjoyed a margin of discretion in exercising banking regulation ${ }^{79}$. As further evidence for a bona fide public purpose, the Tribunal referred to the opinion of the Czech National Bank Appellant Board and the National Court. The Tribunal noted that the reason behind the forced administration was the failure of compliance by the IPB of the Czech Law. Since as a result of this failure the bank's liquidity condition had significantly deteriorated, the stability of the whole banking system was endangered. The forced administration prevented further gradation of the bank's critical situation. The Tribunal supported its line of argumentation by considering the measure's background, i.e. the Czech Republic economic crisis of the late 1990s. It served as evidence for the necessity to act to prevent another crisis. Thus, the Tribunal concluded that for all the above reasons there was a bona fide public purpose to decide in favour of the measure. By assessing the measure's proportionality, the Tribunal weighed the measure's substantial effect against its bona fide public purpose ${ }^{80}$. It found that the critical financial condition of the bank and the potential destabilization that would occur in the Czech Republic outweighed even the measure's substantial effect on the investor ${ }^{81}$. Thus, the measure's bona fide public purpose was given more weight by the Tribunal and a compensable indirect expropriation was denied.

\footnotetext{
Responsibility of States for Injuries to Aliens, the 1967 OECD Draft Convention on the Protection of Foreign Property and the United States Third Restatement of the Law of Foreign Relations in 1987.

77 Ibid. 461.

78 Ibid. 267.

79 Ibid. 272.

80 Ibid. 275.

81 Ibid. 276.
} 


\section{II.2.4. Marfin Investment Group Holdings S.A., Alexandros Bakatselos and Others v. Republic of Cyprus (2018)}

In the case Marfin Investment Group Holdings S.A., Alexandros Bakatselos and Others v. Republic of Cyprus (Marfin v. Republic of Cyprus), the applicable arbitration rules were based on ICSID and the applicable investment treaty between the State and the investor was the Cyprus-Greece BIT. The Greek investor, Marfin Investment Group Holdings S.A., had invested in the Cypriot Bank Laiki, and was controlling it as the major shareholder. In light of the 2012-2013 Cypriot economic crisis, the Central Bank of Cyprus (CBC) requested Emergency Liquidity Assistance from the European Central Bank. This assistance could only be granted if a programme in Cyprus was in place that would ensure the solvency of banks. This programme was negotiated between the commission, the European Central Bank, the International Monetary Fund and Cyprus ${ }^{82}$. Following this programme, the CBC, authorized by the State, bailed-in the Laiki Bank by converting the depositors' deposits into equity. With this measure, the Laiki Bank could increase its core tier 1 capital ratio towards the level mandated by the negotiated programme. This bail-in resulted in the dilution of the investor's shareholding in the Laiki Bank, which was alleged to be an indirect expropriation by the investor. The Tribunal first assessed the measures' effect, second, their bona fide public purpose, third, their non-discriminatory nature, fourth, their compliance with due process and, fifth, whether the measures were proportional. First, regarding the measure's effect, the Tribunal assessed whether the investor's right was sufficiently restricted to support a conclusion that the property was substantially deprived of. It noted that the bail-in measure did not deprive the investor of its investment but, on the contrary, avoided a disorderly collapse of the bank and disastrous effects on the Cypriot economy. At the time of the bail-in, Laiki was in a precarious financial condition and had unsuccessfully attempted to attract strategic investors. Further, and in any event, the evidence in the record did not show that a different measure would have avoided the dilution of the shareholding. Also, the Tribunal considered that the dilution of the shareholders' rights was not excessive to effectively deter private investment. Thus, the Tribunal found that the bail-in did not deprive the investor substantially. Second, the Tribunal assessed the measure's bona fide public purpose. At the time of the State's decision, all

82 Council of the EU, approved Proposal for a Directive of the European Parliament and of the Council establishing a framework for the recovery and resolution of credit institutions and investment firms (2012) 4.4.10, defines bail-ins as the power of the relevant authorities to write down the claims of unsecured creditors of a failing institution and convert debt claims into equity, recapitalizing the failing bank without the use of public money. 
Eurozone leaders were attempting to find solutions at a very difficult turning point for the continent when the future of the entire Eurozone was at stake due to the economic crisis. The Tribunal was persuaded that Cyprus thus faced a difficult political decision and it was not up to an Arbitral Tribunal to sit in judgment over difficult political and policy decisions made by a State ${ }^{83}$. The Tribunal needed not have made precisely the same decision as the regulator to uphold such decisions ${ }^{84}$. Cypriot regulatory authorities were entitled to a certain degree of discretion in making their choice of a recapitalization framework. The Tribunal's assessment was therefore limited to taking into account the above listed factors ${ }^{85}$. The Tribunal again argued that the bail-in was necessary in order to ensure the Bank's very survival and avoided negative systemic effects on Cyprus' economy ${ }^{86}$. Also, Laiki's auditor, external consultants and credit rating agencies shared the Tribunal's view and served as further evidence ${ }^{87}$. The Tribunal thus found that the CBC's bail-in had a bona fide public purpose. Regarding the measure's discriminatory nature, the Tribunal found that the provisions of the bail-in were of general applicability and no different treatment of similar situated cases occurred. For that reason, the Tribunal denied a discrimination ${ }^{88}$. Regarding the investor's due process rights, the Tribunal found that the bail-in was adopted following a process of extensive public consultation ${ }^{89}$. The Tribunal considered that this consultation process respected the investor's due process rights. Regarding the measure's proportionality, the Tribunal weighted the measure's bona fide public purpose against its effect. Since the bona fide public purpose to be protected was the safety of the financial system in the light of an economic crisis, the measure was found to be highly necessary. The Tribunal considered that this bona fide public purpose outweighed the measure's effect since the dilution of the shareholders' rights was not excessive. Moreover, the measure even saved the shareholders rights by avoiding a disorderly collapse of the bank ${ }^{90}$. Thus, the Tribunal held that the bail-in was proportional. For all these reasons, the Tribunal concluded that the bank's bail-in was not a compensable indirect expropriation ${ }^{91}$.

83 Ibid. 872.

84 Ibid. 925, 1035.

85 Ibid. 1056.

86 Ibid. 1037, 1067. The fact that the State's measure was negotiated with and thus supported by international organizations might have also served as further evidence.

87 Ibid. 926, 972, 1031.

88 Ibid. 1062.

89 Ibid. 1055.

90 Ibid. 1087, 1088, 1126.

91 Ibid. 830. The Tribunal also denied the expropriatory nature of another measure, analysing the same factors as elaborated above. See ibid. 889. ff. 


\section{Case Analysis of hypothetical COVID-19 cases}

In this part, I shall apply the findings from above on two hypothetical COVID-19 cases. The first hypothetical case focuses on a public health regulation, whereas the second case focuses on an economic regulation. Even though my case analyses throughout this paper follow this division, they are applicable to every COVID-19 case. This holds true because today's COVID-19 situation is both: A public health and an economic crisis. The measures taken during COVID-19 can be regarded as either public health or economic regulations but moreover, they are both emergency measures. Furthermore, both aspects are interdepended. The current public health crisis caused the current economic crisis, and the current economic crisis worsens the current public health crisis. Hence, the Tribunal would look at both aspects of the pandemic together, i.e. public health aspects and economic aspects, when solving a COVID-19-related case. That is because, the Tribunal must look at all circumstances and the whole context of each case in concreto before making a final decision ${ }^{92}$. It depends on each case in concreto which exact factors and arguments will be considered. Not a single factor was treated as decisive, instead we saw that a global assessment was required. E.g. in the case $L G \& E v$. Argentina, discussed in part II.2.1, the Tribunal made its decision based on the fact that the crisis was a public health and an economic crisis, notwithstanding that the discussed measure was of a pure economic nature. Both aspects became especially relevant in the Tribunal's analysis of the measure's bona fide public purpose and the measure's proportionality.

\section{- Hypothetical Case 1}

Due to COVID-19, State B faces the threat of a collapse of its entire healthcare and economic system. To smoothen the effects of this crisis, State B issued emergency measures, which, inter alia, implied the closing of restaurants for three months in spring, autumn 2020 and in spring 2021. It remains unforeseeable if the emergency measures will be extended. Company A is a foreign investor, which has invested in a restaurant in State B. The investor A claims that its restaurant faces bankruptcy because of the State's emergency measure closing its restaurant for said time. In sum, the investor claims that the State's measure constitutes a compensable indirect expropriation. State B, on the other hand, finds its measure to be an 
integral part of its Police Power. It argues that its measure is based on a state of necessity under its constitutional law, its national laws and the WHO's recommendations, protecting the public from the health harm of COVID-19. The reasoning behind the State's measure is publicly announced regularly. For these reasons, State B responds that its measure constitutes a regulatory, non-compensable, measure and not an expropriation. In State $\mathrm{B}$, there has never been a similar measure before, but it also did not make any commitment to A to refrain from such a measure. Between both States no investment treaty is in place, which could decide on how to handle such a conflict in detail.

\section{Non-Substantial Effect of the Measure}

In casu, the State's measure was only valid for three months, and was thus not permanent. However, the measure came into force again twice and it is unforeseeable if it will be extended. For this reason, the measure is quite long-lasting and restrictive. Still, not all economical use of the investment was being deprived of. The restaurant could, e.g. have set up a delivery service for its food. For this reason, the substantial effect of the measure can be denied.

\section{Bona Fide Public Purpose of the Measure}

Looking at the international verification of the measure's purpose, international organizations affirm the high necessity to act. The WHO declaration of a public emergency of international concern, the WHO guidelines and the UN-Inter Agency Standing Committee guidelines advise to take quarantine measures, involving physical distancing and closing public places. The emergency situation and necessity to act is further affirmed by the IMF, UNCTAD and the World Bank ${ }^{93}$. Both the health and economic aspects of the pandemic thus make it necessary to act immediately. For this reason, all States take similar measures, like closing restaurants. In sum, all the international organizations' recommendations and other State's practices affirm the necessity of the State's measure. Besides this international con-

93 IMF (2020). World Economic Outlook Reports, The Great Lockdown. UNCTAD (2020). Impact of the COVID-19 pandemic on trade and development: transitioning to a new normal. World Bank Group (2020). COVID-19 Crisis Response Approach Paper. Due to the current public health crisis, these institutions also expect the worst economic crisis since the Great Depression of the 1920s and 1930s. 
sensus, the State's national laws serve as further evidence for a bona fide public purpose. Also, scientifically, quarantine measures, like the closing of restaurants, were proofed to help fighting the disease spread. Thus, the measure's bona fide public purpose can be affirmed.

\section{Non-discriminatory nature of the Measure}

There is no discriminatory treatment since the State did not make an unreasonable distinction between similarly situated investors, in this case, between investors in restaurants. The measure applied equally to all foreign owned restaurants and to domestic restaurants. Thus, no discriminatory nature of the measure can be affirmed.

\section{No Legitimate Expectations of the Investor}

First, the government did not give any specific commitments to refrain from emergency measures closing public places. But second, considering the history of the investment activity, the ownership of a restaurant, the investor could not have reasonably foreseen emergency measures regarding its restaurant. This investment activity has not already been restricted similarly in the past. Thus, the investor was not negligent upon analysing the legal issues related to the investment and had legitimate expectations.

\section{Observed Due Process Rights of the Investor}

The debate surrounding the scientific verification process of the measures was open and transparent since the State informed the public daily. Also, no manifest failure of justice can be affirmed since all the State's measures were based on the State's constitutional and national laws. Hence, the investor's due process rights were observed.

\section{Proportionality of the Measure}

To assess the measure's proportionality, first, I shall compare the measure's bona fide public purpose, in light of its necessity, with the measure's effect on the investor. In casu, the bona fide public purpose, in light of the measure's high necessity during a health and economic crisis, outweighs the measure's non-substantial effect. Second, I shall compare the measure's 
bona fide public purpose with the investor's legitimate expectations. Again, in light of the measure's high necessity during a health and economic crisis, the bona fide public purpose of the measure outweighs the investor's legitimate expectations. In the end, the measure's bona fide public purpose could outweigh its effect and the legitimate expectations of the investor and is thus proportional.

\section{- Hypothetical Case 2}

Due to COVID-19, State B faces a deteriorating recession where the major economic indicators start to reach catastrophic proportions and an economic crisis reached its peak. Its unemployment rates skyrocketed. The entire healthcare system faces the risk of a collapse. For these reasons, State B finds itself in a declared state of necessity for four months. Since more people spend their time at home, energy needs of residential consumers grow. However, many people cannot afford to continue paying tariffs to the energy supplying companies. The investment group A is a foreign investor and the major shareholder in one of these companies. State B now issued an emergency measure, based on constitutional and national law. This measure prohibits residential electricity and gas supply disconnections for non-payment of a person experiencing financial hardship related to the $\mathrm{CO}$ VID-19 public health disaster emergency. The moratorium will last for the duration of the crisis. The energy supplying company in which the investor was the major shareholder, had a licensing agreement with State B. To attract foreign investors, in this agreement, State B guaranteed a stable rate of regular tariff returns and in the case of non-payment, the allowance of immediate disconnection. Investor A claims that B's measure indirectly expropriated its investment. Between both parties, no investment treaty is in place, which could decide on how to handle such a conflict in detail.

\section{Substantial Effect of the Measure}

In casu, the measure is only a suspension for the duration of the crisis and thus not permanent. Additionally, the tariffs will be repaid in the future and are thus not abolished permanently. However, it cannot be predicted how long the crisis will last and it is certain that the economy is going to take time to recover afterwards. Thus, due to its unpredictable length, the measure is strongly restrictive. In the case $L G \& E v$. Argentine Republic, the Tribunal found that a tariff reduction was not enough to constitute a substantial deprivation, since the investors did not lose control over their 
shares in the licensees, even though the value of the shares may have fluctuated, nor were they unable to direct the day-to-day operations of the licensees in a manner different than before the measures were implemented. Since also the restrictive tariff suspension in casu meets these conditions and is not a permanent measure, it does not constitute a substantial deprivation.

\section{Bona Fide Public Purpose of the Measure}

Evidence for the measure's bona fide purpose is provided through the State's declaration of a state of necessity. Given this declaration and the evidence of mass unemployment in the state, combined with the catastrophic economic situation and the threatening collapse of the healthcare system, the Tribunal would define the current time as a period of crisis. Since such a crisis threatens the total collapse of the State, it calls for immediate action to smoothen its effects, like the lost ability to pay for tariffs. Also, the fact that the State's measure is justified under national law and that other States reacted similarly would support a finding of a bona fide public purpose. Another argument supporting the bona fide public purpose is that a suspension of a tariff payment could also protect the company and the investor from a total default on the tariffs due to insolvency of the customers, giving them enough time to recover.

\section{Non-discriminatory Nature of the Measure}

There is no discriminatory treatment since the State did not make an unreasonable distinction between similarly situated investors in energy supplying companies. The measure was applied equally to all energy supplying companies. Thus, no discrimination of the investment can be affirmed.

\section{No legitimate Expectations of the Investor}

Since the State signed a guarantee of regular tariff payments at the time of the investment, the investor's legitimate expectations are based on promises offered by the host State at the time of the investment. Also, the investor could not reasonably foresee the current situation, taking the business risk or the industry's regular patterns into account. However, since the State finds itself in a state of necessity, this fact could outweigh the legitimate expectations. Still, since the laid down guarantee in the licensing 
agreement constituted one of the main reasons why the investor invested in the company, the State cannot completely dismantle the very legal framework constructed to attract investors. Thus, in this case, the investor had legitimate expectations.

\section{Observed Due Process Rights of the Investor}

Since the State provided reasonable notice and reasons for its decision, the investor's due process rights were observed.

\section{Proportionality of the Measure}

To assess the measure's proportionality, first, I shall compare the measure's bona fide public purpose, in light of its necessity, with the measure's effect on the investor. The measure's bona fide public purpose, in light of its high necessity during a health and economic crisis, outweighs the non-substantial measure's effect in this case. Second, comparing the measure's bona fide public purpose, again in light of the health and economic crisis, with the investor's legitimate expectations, the bona fide public purpose of the measure outweighs the investor's legitimate expectations. In the end, the measure's bona fide public purpose could outweigh its effect and the legitimate expectations of the investor and is thus proportional.

\section{Conclusion}

In both COVID-19 cases, given the measure's extreme necessity in the light of the crisis, the measure's bona fide public purpose could outweigh the investor's legitimate expectations. My denial of the measure's substantial effect as well as its discriminatory nature also speaks in favour of an outright of the measure's bona fide public purpose. However, even if the measure's effect was substantial and its nature discriminatory, the measure's bona fide public purpose in both COVID-19 cases could have outweighed the former, according to the case analysis in part II.2. Then, the emergency measure would still be considered part of the State's right to regulate. At first glance, this outcome might look as giving preference to the State. This suspicion might even deepen, given the margin of appreciation of the State. Tribunals are not to second guess the correctness of 
science-based or regulatory national decision-making ${ }^{94}$. Given this margin of appreciation, the investor will face a significant challenge in proving an indirect expropriation.

However, I argue that with the mitigated Police Powers doctrine, a balance between the State's and the investor's interest can still be found. The investor is still protected for the following reasons. First, even though the Tribunals are not to second guess the State's decision, they must still assess whether the State's decision was objective ${ }^{95}$. Second, the investor's non-met legitimate expectations and its discriminatory treatment will constitute a breach under another treaty standard ${ }^{96}$ and might for this reason even lead to a compensation payment ${ }^{97}$. Third, by adopting the mitigated Police Powers approach, all Tribunals, by analysing other factors besides the measure's bona fide public purpose, took the investor's needs into account. Fourth, the investor still has the opportunity to demonstrate that the measure amounts to a taking when it involves a disguised purpose or is highly disproportionate to the aim that the host state seeks to achieve. I thus find that with the mitigated Police Powers doctrine, the State has enough regulatory space to act and will not be faced with a "regulatory chill" and neither will it be provided with a carte blanche to act as it pleases.

However, there is no single solution to the general issue of reconciling the State's Police Power and investor's rights in international investment law. Every case is different and must be decided according to its specificities. Each decision thus requires a case-by-case, fact-based inquiry, given not only the evolving nature of the concept, but also the increasing complexity of investments and ever new factual matrixes ${ }^{98}$. Also, even slight differences between investment treaties may affect the final decision ${ }^{99}$. I

94 Chemtura v. Canada (2010) 134. Philipp Morris v. Uruguay (2016) 418. Marfin v. Republic of Cyprus (2018) 872, 925, 1035. Saluka v. Czech Republic (2006) 805, 900. See Waelde/Kolo (2001) 846.

95 Supra note 7.

96 i.e. provisions on: national treatment principle, most favorite nations principle, fair and equitable treatment and minimum standard of treatment. E.g. II.2.1 LG\& E v. Argentina, Decision on Liability (2006). II.2.2 Fireman's Fund v. Mexico (2006).

97 See LG\&E v. Argentine Republic, Award (2007).

98 See Cox (2019) 168.

99 The vast majority of investment treaties do not include guidance as to what constitutes indirect expropriation although it is becoming more common to find clarifications in newer or negotiated BITs as governments attempt to protect their regulatory policy space. E.g. the Senegal-India BIT (2008) Annex 5. UK-Columbia BIT (2010) Art. VI (2). Canada-Burkina Faso BIT (2014) Annex 1: "Except in rare cases, non-discriminatory regulatory actions will not usually constitute expropriation". However, the difficulty remains in identifying the rare circumstances, thus, the legitimacy of the analyzed factors above will remain of critical importance. 
hence wish to emphasize that the findings of my COVID-19 cases need to be applied in the light of the specific cases' context, which is the context of a public health and economic crisis and of a State's bona fide intent. My case solutions might differ in other cases, e.g. where no crisis is involved, other policy objectives are pursued or the measure's purpose is mala fide. As the Tribunal in Saluka v. Czech Republic stated: "International investment law has yet to identify in a comprehensive and definitive fashion precisely what regulations are considered permissible and commonly accepted as falling within the Police Power of States" ${ }^{100}$. While there is no bright general line, this paper can still serve as a guiding for investors and States to look for a similar situated case. As mentioned before, such cases, due to a de facto stare decisis, will be treated similarly ${ }^{101}$. Even though not all introduced factors were applied in each case, to have more predictability, I recommend a State to include all these six factors and thus the mitigated Police Powers doctrine in its decision making. The investor, on the other hand, is recommended to look for the assessed factors in the State's measure when considering submitting a claim. Additionally, the investor is well advised to rely on other treaty provisions besides the rule on indirect expropriation ${ }^{102}$. In sum, this is my legal answer to COVID-19 in investment arbitration, which can hopefully give some predictability in todays' unpredictable situation.

\section{Bibliography}

Black, C. H. (1990). Black's Law Dictionary. $6^{\text {th }}$ ed. St. Paul. West Publishing Co.

Blankenburg, G. J. (2009). "The Global Financial Crisis”. Cambridge Journal of Economics 33 (4).

Bonnitcha, J. (2004). Substantive Protection Under Investment Treaties: A Legal and Economic Analysis. Cambridge. Cambridge University Press.

Bücheler, G. (2015). Proportionality in Investor-State Arbitration. Oxford. OUP Oxford.

Christie, G. (1962). "What Constitutes a Taking of Property under International Law?". British Yearbook of International Law 38 (307).

100 Saluka v. Czech Republic (2006) 356. See UNCTAD (2007). Investor-State Dispute Settlement and Impact on Investment Rulemaking 57.

101 Supra note 7.

102 Other Treaty provisions must be looked at as well, since they can lead to a compensation payment as seen in the case $L G \& E$ v. Argentina, Decision on Liability (2006). See II.2.1. Had the investor in the case Fireman's Fund v. Mexico (2006) based its claim on different treaty provisions besides the one on expropriation, he would have been compensated. See II.2.2. 
Cox, J. (2019). Expropriation in Investment Treaty Arbitration. New York. Oxford International Arbitration Series.

Fortier, Y.; Drymer, S.; Ratner, S. (2008). "Regulatory Takings in Institutional Context: Beyond the Fear of Fragmented International Law". American Journal of International Law 102 (475).

Friedman, S. (1953). Expropriation in International Law. London. Stevens.

Galva, J.; Atchison, C.; Levey, S. (2005). "Public Health Strategy and the Police Powers of the State". Public Health Reports 120.

Gross, S. (2002). "Inordinate Chill: BITs, Non-NAFTA MITs and Host-State Regulatory Freedom - An Indonesian Case Study". Michigan Journal of International Law 24.

Herz, J. (1941). "Expropriation of Foreign Property". American Journal of International Law 35 (243).

Kaufmann-Kohler, G. (2007). “Arbitral Precedent: Dream, Necessity or Excuse?”. Arbitration International Law Journal 23 (357).

Legarre, S. (2007). "The Historical Background of the Police Power". Journal of Constitutional Law, Notre Dame Legal Studies Paper 9 (1413).

Ranjan, P. (2020). "COVID-19, India And Indirect Expropriation: Is the Police Powers Doctrine, a Reliable Defence”. Contemporary Asia Arbitration Journal 13 (1).

Tienhaara, K. (2011). "Regulatory chill and the threat of arbitration: A view from political science". In: Brown Chester \& Miles Kate [ed.]. Evolution in Investment Treaty Law and Arbitration. Cambridge. Cambridge University Press.

Waelde, T.; Abba, K. (2001). "Environmental Regulation, Investment Protection and Regulatory Taking in International Law". International and Comparative Law quarterly 50.

\section{Documents}

American Law Institute. (1987). Restatement (Third) Foreign Relations of the United States 1 (712) comment (g).

Council of the EU. (2012). Approved Proposal for a Directive of the European Parliament and of the Council establishing a framework for the recovery and resolution of credit institutions and investment firms.

Garcia-Amador F.V. (1959). Special rapporteur, Fourth Report on State Responsibility, Extract from the Yearbook of the International Law Commission 2 (44).

Harvard Draft Convention on International Responsibility of States. (1961). Art. $10(5)$.

IMF (2020). World Economic Outlook Reports, The Great Lockdown.

IMF (1999). Working Paper, The 1994 Mexican Economic Crisis (1999).

UNCTAD (2020). Impact of the COVID-19 pandemic on trade and development: transitioning to a new normal.

UNCTAD (2020). Impact of the COVID-19 pandemic on trade and development: transitioning to a new normal. UNCTAD/OSG/2020/1. 
UNCTAD (2020). Investment Policy Responses to the COVID-19 Pandemic, Investment Policy Monitor Special Issue (4).

UNCTAD (2012). Expropriation, A Sequel. UNCTAD/DIAE/IA/2011/7. New York and Geneva

UNCTAD (2019). Trade and Development Board, Investment, Enterprise and Development Commission. $11^{\text {th }}$ session. Recent developments in the international investment regime: Taking stock of phase 2 reform actions (9).

OECD (2017). The Role of Economic Regulators in the Governance of Infrastructure.

OECD (2004). Working Paper on International Investment, Indirect Expropriation and the Right to Regulate in International Investment Law (5).

World Bank Group (2020). COVID-19 Crisis Response Approach Paper.

\section{Table of Treaties}

Agreement between the Government of Canada and the Government of Burkina Faso for the Promotion and Protection of Investments (Canada-Burkina Faso BIT), signed on 30-11-2014, entered into force 11-10-2017.

Agreement between the Government of Cyprus and the Government of Greece for the Promotion and Reciprocal Protection of Investments (Cyprus-Greece BIT), signed on 30-3-1992, entered into force on 26-2-1993.

Agreement on the Promotion and Reciprocal Protection of Investments between the United Mexican States and the Kingdom of Spain (Mexico-Spain BIT), signed on 23-6-1995, entered into force on 18-12-1996, terminated on 3-4-2008.

Agreement on Encouragement and Reciprocal Protection of Investments between the Kingdom of the Netherlands and the Czech and Slovak Federal Republic (Netherlands-Czech Republic BIT), signed on 29-4-1991.

Agreement between the Government of the Republic of India and the Government of the Republic of Senegal for the Promotion and Protection of Investments (Senegal-India BIT), signed on 3-7-2008, entered into force on 17-10-2009.

Agreement between the Swiss Confederation and the Oriental Republic of Uruguay OD the Reciprocal Promotion and Protection of Investments (Switzerland-Uruguay BIT) signed on 7-10-1988, entered into force on 22-4-1991, entered into force on 29-4-1992.

EU-Singapore-Free Trade Agreement, signed on 19-10-2018, entered into force on 13-2-2019.

ICSID Convention - Convention on the Settlement of Investment Disputes between States and Nationals of Other States, 575 UNTS 159, signed on 18-3-1965, entered into force 14-10-1966.

ICSID Additional Facility Rules, ICSID/11/rev. 1, approved on 29-9-2002, entered into force 1-1-2003.

North American Free Trade Agreement, 32 ILM 289, signed on 17-12-1992, entered into force 1-1-1994.

UNCITRAL, adopted by the General Assembly on 15 December 1976. 
The Comprehensive and Economic Trade Agreement between the European Union and the Government of Canada, signed on 30-10-2016, entered into force provisionally on 21-9-2017.

The Stockholm Convention on Persistent Organic Pollutants, adopted on 22-5-2001, entered into force on 17-5-2004.

Treaty Between the Government of Argentina and the Government of the U.S. concerning the Reciprocal Encouragement and Protection of Investments (Argentina-U.S. BIT), signed on 14-11-1991, entered into force on 20-10-1994.

Vienna Convention on the Law of Treaties, 1155 UNTS 331, signed on 23-5-1969, entered into force on 27-1-1980.

\section{Table of Cases}

\section{Investment Arbitration Cases}

Caratube International Oil Company LLP v. Kazakhstan, Saipem S.p.A. v. Bangladesh, ICSID Case No. ARB/08/12, Decision on Jurisdiction of March 212007.

Chemtura Corporation v. The Government of Canada, UNCITRAL, Award, 2 August 2010 (Chemtura v. Canada).

CME Czech Republic v. Czech Republic, UNCITRAL, Partial Award, 13 September 2001.

EDF (Services) Limited v. Romania, ICSID Case No. ARB/05/13, Award, 8 October 2009.

El Paso Energy International Company v. The Argentine Republic, ICSID Case No. Arb/03/15, Award, 31 October 2011.

Electrabel S.A. v. Republic of Hungary, ICSID Case No. ARB/07/19, Decision on Jurisdiction, Applicable Law and Liability, 30 November 2012.

Fireman's Fund Insurance Company $v$. The United Mexican States, ICSID Case No. ARB(AF)/02/1, Award, 17 July 2006 (Fireman's Fund v. Mexico).

Glamis Gold Ltd v. United States of America, UNCITRAL, Award, 8 June 2009.

LG\&E Energy Corp., LG\&E Capital Corp. and LG\&E International Inc. v Argentine Republic, ICSID Case No. Arb/02/1, Decision on Liability, 3 October 2006 (LG\&E $v$. Argentine Republic, Decision on Liability).

$L G \& E$ Energy Corp., LG\&E Capital Corp. and LG\&E International, Inc. v. Argentine Republic, ICSID Case No. ARB/02/1, Award, 25 July 2007 (LG\&E v. Argentine Republic, Award).

Loewen Group, Inc. and Raymond L. Loewen v. United States of America, ICSID Case No. ARB(AF)/98/3, 26 June 2003.

Marfin Investment Group Holdings S.A., Alexandros Bakatselos and Others v. Republic of Cyprus, ICSID Case No. ARB/13/27, 26 July 2018 (Marfin v. Republic of Cyprus).

Marvin Feldman v Mexico, ICSID Case No. ARB (AF)/99/1, Award, 16 December 2002. 
Methanex Corporation v. United States of America, UNCITRAL, Final Award, 3 August 2005 (Methanex v. U.S.).

Philip Morris Brands Sàrl and ors v. Oriental Republic of Uruguay, ICSID Case No. ARB/10/07, Award, IIC 844 (2016), 28 May 2016 (Philipp Morris v. Uruguay).

Pope \& Talbot Inc $v$. The Government of Canada, UNCITRAL, Interim Award, IIC 192 (2000), 26 June 2000.

Renee Rose Levy de Levi v. The Republic of Peru, ICSID Case No. ARB/10/17, Award, IIC 728 (2014), 26 February 2014.

Quiborax S.A., Non Metallic Minerals S.A. and Allan Fosk Kaplún v. Plurinational State of Bolivia, ICSID Case No. ARB/06/2, Final Award, 16 September 2015.

Saluka Investments BV v. The Czech Republic, UNCITRAL, Partial Award, IIC 210 (2006), 17 March 2006, PCA (Saluka v. The Czech Republic).

S.D. Myers, Inc. v. Government of Canada, NAFTA/UNCITRAL, Partial Award, 11 November 2000.

Técnicas Medioambientales Tecmed S.A. v. United Mexican States, ICSID Case No. ARB (AF)/00/2, Award, 29 May 2003 (Tecmed v. Mexico).

Waste Management, Inc. v. United Mexican States, ISCID, Case No ARB(AF)/00/3, Final Award, 30 April 2004.

\section{International Law Cases}

Broniowski v. Poland, ECtHR, Case No. 31443/96, Judgment, 22 June 2005.

James and others $v$. United Kingdom, ECtHR, Case No. 8793/ /79 (A/98), Judgment, 21 February 1986.

Matos e Silva, Lda., and Others v. Portugal, ECtHR, Case no. 15777/89, Judgment, 16 September 1996.

Mellacher and Others v. Austria, ECtHR, Case No. 10522/83; 11011/84; 11070/84, Judgment, 19 December 1989.

Oscar Chinn affair (U.K. v. Belgium), P.C.I.L., Case No. 63, Judgment, 12 December 1934.

Pressos Compañía Naviera and Others v. Belgium, ECtHR, Case no. 17849/91, Judgment, 20 November 1995. 